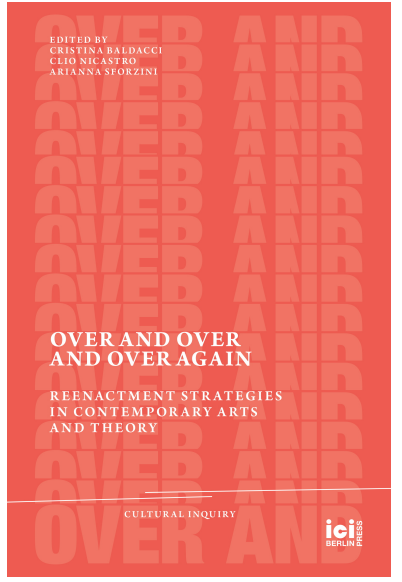

Over and Over and Over Again: Reenactment Strategies in Contemporary Arts and Theory, ed. by Cristina Baldacci, Clio Nicastro, and Arianna Sforzini, Cultural Inquiry, 21 (Berlin: ICI Berlin Press, 2022), pp. 91-98
ROBERTA AGNESE

\section{Archival Reenactement and the Role of Fiction}

\author{
Walid Raad and the Atlas Group Archive
}

CITE AS:

Roberta Agnese, 'Archival Reenactement and the Role of Fiction: Walid Raad and the Atlas Group Archive', in Over and Over and Over Again: Reenactment Strategies in Contemporary Arts and Theory, ed. by Cristina Baldacci, Clio Nicastro, and Arianna Sforzini, Cultural Inquiry, 21 (Berlin: ICI Berlin Press, 2022), pp. 91-98 <https://doi.org/10.37050/ci-21_10>

\section{RIGHTS STATEMENT:}

(C) by the author(s)

Except for images or otherwise noted, this publication is licensed under a Creative Commons Attribution-ShareAlike 4.0 International License.

ABSTRACT: The Atlas Group created a digital mixed-media archive of contemporary Lebanese history, made up of produced and found documents. These archives look immediately ambiguous: they don't collect historical documents; they actually contain visual artefacts created by the Lebanese artist Walid Raad. These digital mixed-media archives - partly accessible on the web but also physically exhibited and performed - are not intended to preserve the memory of the past, but they become indeed useful to actualize history by giving it back in the form of a historical fiction. What if archives should not deal with memory, but with amnesia? And what kind of historical temporality do they re-activate?

KEYWORDS: Atlas Group; Archive; History; Memory; Photography 


\title{
Archival Reenactement and the Role of Fiction
}

\author{
Walid Raad and the Atlas Group Archive \\ ROBERTA AGNESE
}

Talking about the dialectical image, Walter Benjamin borrows an illuminating comparison from the French historian André Monglond. In the fragment that Benjamin quotes, Monglond describes the resemblances between the ability of a literary text to show and introduce meanings that appear mysterious to contemporary readers and the way that photographic images are impressed on a photosensitive plate and then revealed:

The past has left images of itself in literary texts, images comparable to those which are imprinted by light on a photosensitive plate. The future alone possesses developers active enough to scan such surfaces perfectly. ${ }^{1}$

The concept of the 'dialectical image', of the image that is 'dialectics at a standstill', is at the core of Benjamin's materialist thought of history, a concept that explores and reveals the dialectical relationship between the what-has-been and the now. For Benjamin, this relationship is deeply different from the temporal relationship between the

1 Walter Benjamin, The Arcades Project, ed. by Rolf Tiedemann, trans. by Howard Eiland and Kevin McLaughlin (Cambridge, MA: Harvard University Press, 1999), p. 482.

2 Ibid., p. 463. 
past and the present, because it is 'not temporal in nature, but figural (bildlich). ${ }^{3}$ The image is, in this sense, the moment when 'what has been comes together in a flash with the now to form a constellation'; it is the 'perilous critical moment' of the now of recognizability. ${ }^{4}$ Thus history, in this perspective, has to be conceived as a construction, a montage made of different temporal layers in which the historical images are those moments (Augenblicke) of recognizability, through which the past as what-has-been can be known and recognized in an unpredictable way, in a constellation of times and meanings that appears understandable only at a particular moment. This montage is what Benjamin calls the 'historical index' of images, which creates the possibility to recall the past in the present through images that can be read or that become readable at a specific moment in time. ${ }^{5}$ The image as 'dialectics at a standstill' is thus a figural crystallization of disjointed temporalities: the past deposes itself, and the future can reveal it, but only in their collision in the flash of the now of recognizability can the past be reactivated, shaped, and reshaped. Consequently, the dialectical image works as a sort of photosensitive plate of history: the past leaves its images on it, but only the future has developers active enough to show and reveal all the details.

A meaningful example of shaping, reactivating, and questioning the past through dialectical images is the vast project The Atlas Group Archive ${ }^{6}$ by the Lebanese artist Walid Raad, who acts, in a Benjaminian sense, as a materialist historian and a political artist at the same time. Through his work, I would like to consider the reenactment in visual artistic practices as a way of reactivating the past in the present, not as a repetition or a restaging, but as a specific way of questioning that past by 'fictioning' a disregarded history through images. ${ }^{7}$

\footnotetext{
3 Ibid.

4 Ibid., pp. 462-63.

5 Ibid., p. 462.

6 To see a selection of the works that constitute the project: The Atlas Group, (19892004), artist website <https://www.theatlasgroup1989.org/> [accessed 20 January $2021]$.

7 Throughout this chapter, I use this term according to the English translation of the French neologism, 'fictionner', which Michel Foucault introduced in the text 'Les Rapports de pouvoir passent à l'intérieur des corps', interview with Lucette Finas, $\mathrm{La}$ Quinzaine littéraire, 247 (January 1977), pp. 4-6 (p. 6) (repr. in Foucault, Dits et écrits, ed. by Daniel Defert, François Ewald, and Jacques Lagrange, 4 vols (Paris: Gallimard,
} 
The Atlas Group Archive is a composite artistic project that presents itself as 'established to research and document' contemporary Lebanese history, especially the history of the fifteen-year long Lebanese Civil War. This war officially ended in 1991, when a General Amnesty Law was enacted by the Lebanese parliament. This law, which was largely controversial, granted amnesty for the crimes committed during the war and passed with the aim of a quick restoration and pacification of the country. Instead, it contributed to the instauration in post-war Lebanon of what has been defined by several specialists and scholars as 'a state-sponsored amnesia., It produced a 'collective forgetfulness' for those who lived the war, who were the 'victims of a lacuna between personal memory and collective amnesia', and the war therefore lingered in a state of latency and the past came to 'appear unreal. 9

For a past that seems to have become unreal, what form does an archive of such dematerialized events have to assume? In a context where a growing opacity covers the past, where - as it has been observed - 'amnesty and amnesia were [...] conscious policies,', ${ }^{10}$ how can one manage to shape a historical discourse that is missing but necessary? How can one build a collective memory, when the 'interdiction to remember' is taken as the basis for a renewed public life?

The Atlas Group tries to cope with these kinds of questions. The Atlas Group Archive is thus an archive, but a weird one: it is made up of documents as well as artefacts, presented in a digital mixed-media form, documents that are found but also produced and attributed to 'named imaginary individuals or organizations', 'anonymous individuals or organizations', and the Atlas Group itself. ${ }^{11}$ These archives look

1994), III: 1976-1979, pp. 228-36 (p. 236)); in English as 'The History of Sexuality', in his Power/Knowledge: Selected Interviews and Other Writings, 1972-1977, ed. by Colin Gordon (New York: Pantheon Books, 1980), pp. 183-94 (p. 193). I think that the use of this neologism is particularly meaningful here, since it underlines the fiction as being not only a result or a goal, but a process, a method, an operation in itself, which is at the same time a technical and an artistic one. See also note 11.

8 Samir Kassir, 'Dix ans après, comment ne pas réconcilier une société divisée?', Monde Arabe Maghreb Machrek, 169 (2000), pp. 6-22, quoted in Sune Haugbolle, War and Memory in Lebanon (Cambridge: Cambridge University Press, 2010), p. 71.

9 Haugbolle, War and Memory, p. 72.

10 Ibid., p. 71.

11 Walid Raad, Miraculous Beginnings (London: Whitechapel Gallery, 2010), p. 23. 
immediately ambiguous: they do not collect historical documents; instead, they contain visual artefacts created by Raad, who worked on the project from 1989 until 2004.

As a counterpoint to the institutional and historical fiction enacted by the amnesty, a fiction that has a performing influence on past and present, where we politically act as if something never occurred, ${ }^{12}$ Raad decides to build a fictional archive of a past that becomes 'unreal', with the aim to question the limits and the possibilities of writing the history of contemporary Lebanon and to experience the possibility to reactivate in the present a rejected past.

These colours, lines and forms are all borrowed from different documents. [...] I produce an image by borrowing historical facts. I always work from facts but some of these facts can only be experienced in a place we call fiction. ${ }^{13}$

With this project, Raad manufactures and 'fictions' historical materials by establishing an archive, not to assert their truth, but to make these fictions function in a necessary discourse of truth. He does not search for factual or historical knowledge of the events he collects in this strange archive; rather, he displays those events by 'fictioning' their truth potential. As Michel Foucault affirms:

[T] he possibility exists for fiction to function in truth, for a fictional discourse to induce effects of truth, and for bringing it about that a true discourse engenders or 'manufactures' something that does not as yet exist, that is, 'fictions' it. One 'fictions' a politics not yet in existence on the basis of a historical truth. ${ }^{14}$

12 As a historical and political fiction - since we pretend that something never happened - amnesty has a performative impact on the past and on time by posing oblivion as a founding act to renew our life as a community. French historian Nicole Loraux, in her book The Divided City: On Memory and Forgetting in Ancient Athens, trans. by Corinne Pache and Jeff Fort (New York: Zone Books, 2006) reminds us that amnesty acts "as if the present were thinkable only in the past, on condition, however, that the past, stripped of all potentially subversive value, only be used as an edifying model. To disarm, one by the other, the present and the distant past: this is political memory's great strategy for forgetting the most recent past" (p. 261). This legal, temporal and historical fiction takes the form of an erasure, of an " institutional obliteration of those chapters of civic history that the city fears time itself is powerless to transform into past events". (p. 145). On political and historical consequences of the civil war see also Giorgio Agamben, Stasis: Civil War as a Political Paradigm, trans. by Nicholas Heron (Stanford, CA: Stanford University Press, 2015).

13 Walid Raad, Miraculous Beginnings, p. 14.

14 Foucault, 'The History of Sexuality', p. 193. 
The Atlas Group Archive is therefore not intended to preserve the memory of the past, because they are not based memory - but amnesia. These archives are useful in deconstructing contemporary Lebanese history into pieces and reshaping it, or reenacting it, by creating fictional documents that work as dialectical images or as fictional politics able 'to induce effects of truth' in the present that they address.

I would like to end by briefly considering a specific section of this archive, Secrets in the Open Sea.

Secrets in the open sea consists of 6 large photographic prints that were found buried 32 meters under the rubble during the 1992 demolition of Beirut's war-ravaged commercial district. The prints were different shades of blue. [...] In late 1994, The Atlas Group sent the prints to laboratories in France and in the United States for technical analysis. Remarkably, the laboratories recovered small black and white latent images from the prints, and the small images represent group portraits of men and women. The Atlas Group was able to identify all the individuals represented in the small black and white prints, and it turned out that they were all individuals who had been found dead in the Mediterranean sea between 1975 and $1990 .{ }^{15}$

The six plates that comprise this section appear to be monochrome representations of six different shades of blue. Raad says, 'I have rarely considered monochrome paintings I have encountered as empty screens, but rather as surfaces too much filled [...] by their own material. ${ }^{16}$ Upon closer viewing, we discover that those plates are in fact not monochrome paintings, but six digital photographic colour prints filled with another fundamental element: in addition to the big blues, we can observe, in the bottom right, a faded black and white photograph, which is supposed to be the latent image discovered by the laboratories.

The blue of the Mediterranean Sea thus becomes a material and symbolic layer that hides latent images. The blue becomes a documentary colour, as Raad observes:

I have the impression to document a colour that is not yet available as a referential element, as documentary. [...] [B]y

15 Raad, Miraculous Beginnings, p. 61.

16 Ibid., p. 17. 


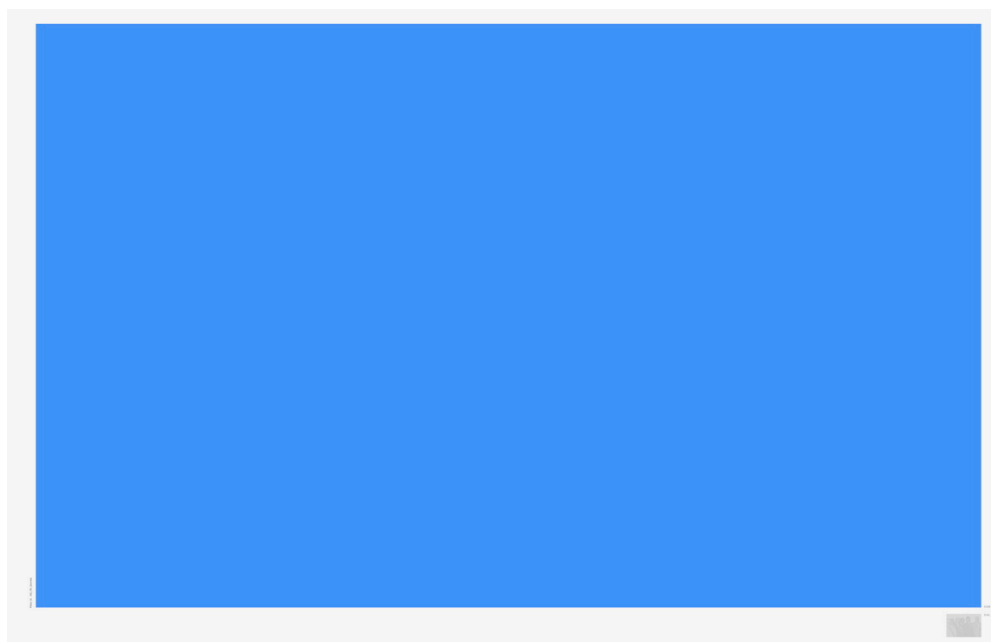

Figure 1. Anonymous, The Atlas Group, Secrets In the Open Sea (1994-2004), Color digital print, $111.76 \times 175 \mathrm{~cm} / 1$, Courtesy of the artist and Sfeir-Semler Gallery, Beirut / Hamburg.

documenting this colour, I feel I become the recipient of a letter that I have to save for a future addressee. ${ }^{17}$

The latency of images addresses future recipients who will have to explore all the layers of this faded memory and will be able to reactivate Raad's gesture, because only the future has developers active enough to reveal the details. This latency is a state of apparent inactivity but also a delay, an expectation, a wait in the camera obscura for an image to reveal itself, to discover the fate of those 17,000 women and men kidnapped during the war and still missing.

These black and white photos come from Lebanese newspapers of the 1990s. They are not the 'real' portraits of those who are missing; they are only possible — not to say fictional — portraits that stand in as faces and bodies of anonymous victims of the war. This intermedial superimposition questions all kinds of testimony and narration, all kinds of documentary truthfulness, not by fostering an iconoclastic position, but by waiting for a figuration in the present. The viewer is always required to reactivate the gesture that leads to the creation of

17 Ibid., p. 14. 


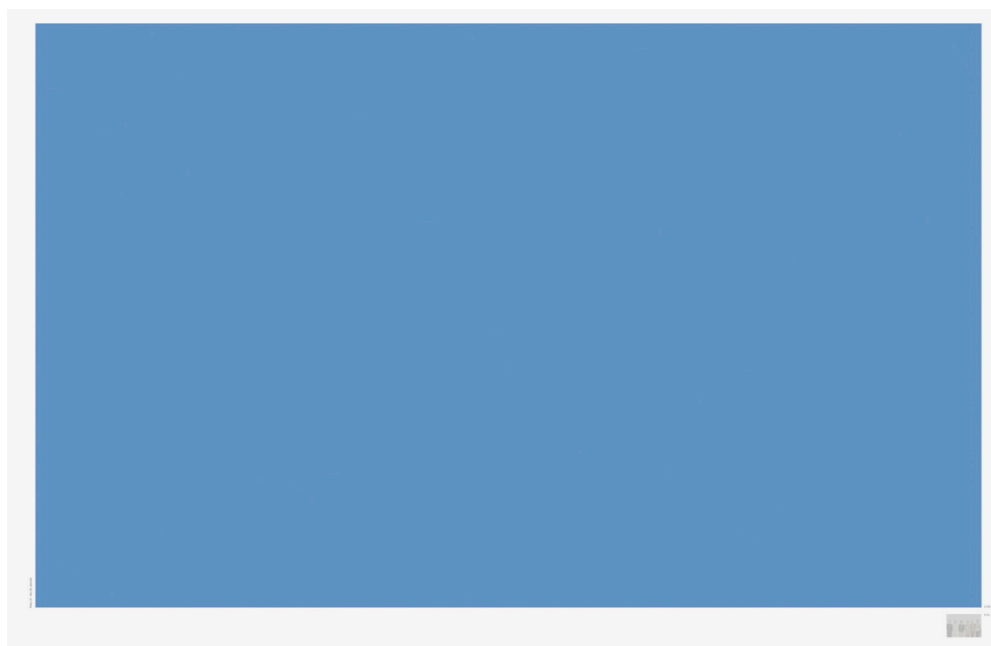

Figure 2. Anonymous, The Atlas Group, Secrets In the Open Sea (1994-2004), Color digital print, $111.76 \times 175 \mathrm{~cm} / 3$, Courtesy of the artist and Sfeir-Semler Gallery, Beirut / Hamburg.

Raad's documents, because the present that looks at this history is the very subject of Raad's work and has to recognize itself in those dialectical images for the process to be complete.

In this sense, Raad's gesture acquires a specific political value: which relationship does the present forge with history and memory, in the critical and perilous moment of recognizability?

By fictioning a disregarded history, Raad makes it emerge and work in our present, he opens up the possibility for configuring a 'politics not yet in existence ${ }^{18}$ by inventing documents, in an etymological sense - that is to say, by finding and discovering them, and at the same time by creating something new. Raad discovers and finds the testimonies he displays in this sense; he invents his documents by excavating and searching in a specific space and time. But he also borrows facts and shapes them, integrating them in an aesthetical and fictional operation. Archives are no longer closed within a classificatory order, and documents are no longer shut away within them; instead, both are

18 Foucault, 'The History of Sexuality', p. 193. 

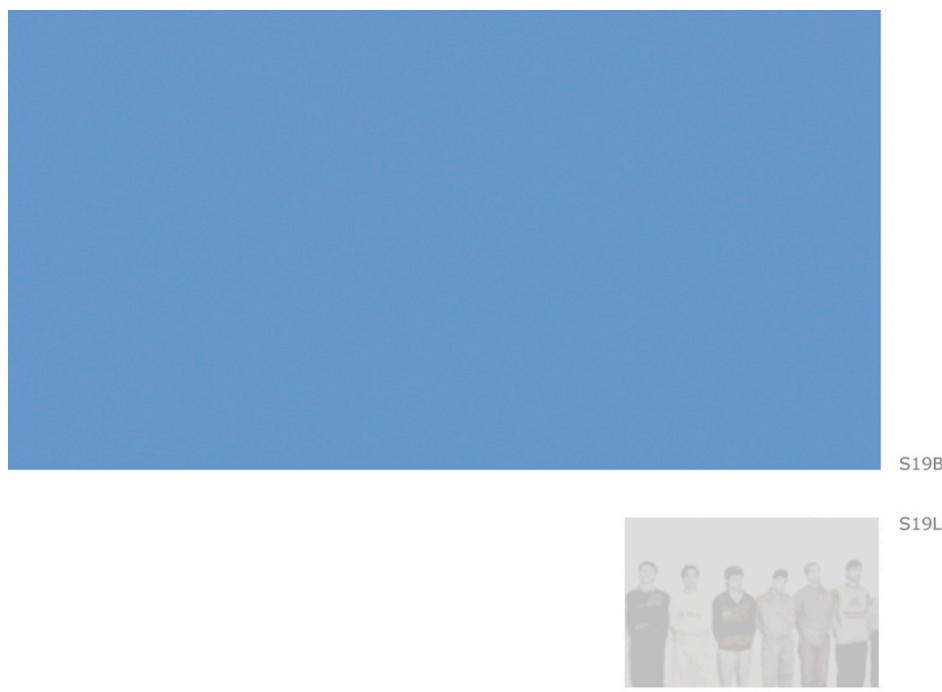

Figure 3. Anonymous, The Atlas Group, Secrets In the Open Sea (1994-2004), Color digital print, $111.76 \times 175 \mathrm{~cm} / 3$, Detail, Courtesy of the artist and Sfeir-Semler Gallery, Beirut / Hamburg.

renewed by Raad's gesture and they can, in this way, continue to have effects in the present. As Raad says:

The story one tells oneself and that captures ones attention and belief may have nothing to do with what happened in the past, but that's the story that seems to matter in the present and for the future. ${ }^{19}$

19 Quoted in Kassandra Nakass, 'Double Miss: On the Use of Photography in the Atlas Group Archive', in The Atlas Group (1989-2004): A Project by Walid Raad, ed. by Kassandra Nakass and Britta Schmitz (Cologne: Walther König, 2006), pp. 49-52 (p. $52)$. 
Roberta Agnese, 'Archival Reenactement and the Role of Fiction: Walid Raad and the Atlas Group Archive', in Over and Over and Over Again: Reenactment Strategies in Contemporary Arts and Theory, ed. by Cristina Baldacci, Clio Nicastro, and Arianna Sforzini, Cultural Inquiry, 21 (Berlin: ICI Berlin Press, 2022), pp. 91-98<https://doi.org/10.37050/ci-21_10>

\section{REFERENCES}

Agamben, Giorgio, Stasis: Civil War as a Political Paradigm, trans. by Nicholas Heron (Stanford, CA: Stanford University Press, 2015)

The Atlas Group (1989-2004), artist website < https://www.theatlasgroup 1989.org/> [accessed 20 January 2021]

Benjamin, Walter, The Arcades Project, ed. by Rolf Tiedemann, trans. by Howard Eiland and Kevin McLaughlin (Cambridge, MA: Harvard University Press, 1999)

Foucault, Michel, 'The History of Sexuality', in Foucault, Power/Knowledge: Selected Interviews and Other Writings, 1972-1977, ed. by Colin Gordon (New York: Pantheon Books, 1980), pp. 183-94

_ 'Les Rapports de pouvoir passent à l'intérieur des corps', interview with Lucette Finas, La Quinzaine littéraire, 247 (January 1977), pp. 4-6 (repr. in Foucault, Dits et écrits, ed. by Daniel Defert, François Ewald, and Jacques Lagrange, 4 vols (Paris: Gallimard, 1994), III: 1976-1979, pp. 228-36)

Haugbolle, Sune, War and Memory in Lebanon (Cambridge: Cambridge University Press, 2010) <https://doi.org/10.1017/CBO9780511676598>

Kassir, Samir, 'Dix ans après, comment ne pas réconcilier une société divisée?', Monde Arabe Maghreb Machrek, 169 (2000), pp. 6-22

Loraux, Nicole, The Divided City: On Memory and Forgetting in Ancient Athens, trans. by Corinne Pache and Jeff Fort (New York: Zone Books, 2006)

Nakass, Kassandra, 'Double Miss: On the Use of Photography in the Atlas Group Archive', in The Atlas Group (1989-2004): A Project by Walid Raad, ed. by Kassandra Nakass and Britta Schmitz (Cologne: König, 2006), pp. 49-52

Raad, Walid, Miraculous Beginnings (London: Whitechapel Gallery, 2010) 